\title{
Prediction of urinary nitrogen and urinary urea nitrogen excretion by lactating dairy cattle in northwestern Europe and North America: A meta-analysis
}

\author{
J. W. Spek, ${ }^{*} \dagger^{1}$ J. Dijkstra, ${ }^{*}$ G. van Duinkerken, $\dagger$ W. H. Hendriks, ${ }^{*}$ and A. Bannink $\dagger$ \\ *Animal Nutrition Group, Wageningen University, PO Box 338, $6700 \mathrm{AH}$, Wageningen, the Netherlands \\ †Wageningen UR Livestock Research, PO Box 65, 8200 AB, Lelystad, the Netherlands
}

\begin{abstract}
A meta-analysis was conducted on the effect of dietary and animal factors on the excretion of total urinary nitrogen (UN) and urinary urea nitrogen (UUN) in lactating dairy cattle in North America (NA) and northwestern Europe (EU). Mean treatment data were used from 47 trials carried out in NA and EU. Mixed model analysis was used with experiment included as a random effect and all other factors, consisting of dietary and animal characteristics, included as fixed effects. Fixed factors were nested within continent (EU or NA). A distinction was made between urinary excretions based on either urine spot samples or calculated assuming a zero $\mathrm{N}$ balance, and excretions that were determined by total collection of urine only. Moreover, with the subset of data based on total collection of urine, a new data set was created by calculating urinary $\mathrm{N}$ excretion assuming a zero $\mathrm{N}$ balance. Comparison with the original subset of data allowed for examining the effect of such an assumption on the relationship established between milk urea $\mathrm{N}$ (MUN) concentration and UN. Of all single dietary and animal factors evaluated to predict $\mathrm{N}$ excretion in urine, MUN and dietary crude protein $(\mathrm{CP})$ concentration were by far the best predictors. Urinary $\mathrm{N}$ excretion was best predicted by the combination of MUN, CP, and dry matter intake, whereas UUN was best predicted by the combination of MUN and CP. All other factors did not improve or only marginally improved the prediction of UN or UUN. The relationship between UN and MUN differed between NA and EU, with higher estimated regression coefficients for MUN for the NA data set. Precision of UN and UUN prediction improved substantially when only UN or UUN data based on total collection of urine were used. The relationship between UN and MUN for the NA data set, but not for the EU data set, was substantially altered when UN was calculated assuming a zero $\mathrm{N}$ balance instead of being based on the total collection of urine. According to results of the present
\end{abstract}

Received October 13, 2012.

Accepted March 29, 2013.

${ }^{1}$ Corresponding author: wouter.spek@wur.nl meta-analysis, UN and UUN are best predicted by the combination of MUN and $\mathrm{CP}$ and that, in regard to precision and accuracy, prediction equations for UN and UUN should be derived from the total collection of urine.

Key words: milk urea nitrogen, urinary nitrogen, dairy cattle, meta-analysis

\section{INTRODUCTION}

Nitrogen $(\mathrm{N})$ losses via excreted feces and urine in dairy cattle are associated with losses of $\mathrm{N}$ from the farming system through ammonia volatilization, nitrate leaching, and dissipation of $\mathrm{N}$ as $\mathrm{N}_{2} \mathrm{O}, \mathrm{NO}$, and $\mathrm{NO}_{2}$ (de Vries et al., 2001). With regard to such environmental concerns, great interest has been noted in investigating the potential of specific on-farm measures to reduce $\mathrm{N}$ losses, preferably without reducing milk production. Nitrogen digested and not excreted as milk protein is, in large part, excreted as urea $\mathrm{N}$ in urine. On-farm indicators including MUN concentration ( $\mathrm{mg}$ of $\mathrm{N} / \mathrm{dL}$ ) may be attractive to monitor the excretion of urinary urea N (UUN; g of $\mathrm{N} / \mathrm{d}$ ) or total urinary $\mathrm{N}$ (UN; $\mathrm{g}$ of $\mathrm{N} / \mathrm{d}$ ). Several studies focused on the relationship between MUN and UN (Jonker et al., 1998; Kauffman and St-Pierre, 2001; Nousiainen et al., 2004; Zhai et al., 2005; Zhai et al., 2007). Jonker et al. (1998) and Nousiainen et al. (2004) performed meta-analyses analyzing the relationship between MUN and UN on data sets containing data from multiple trials. Published meta-analyses have either been based solely on data from North America (NA) or data from northwestern European countries (EU). Jonker et al. (1998) based their analysis on 3 NA trials, whereas Nousiainen et al. (2004) based their analysis on a large data set of $50 \mathrm{EU}$ trials with grass-silage-based diets. In all trials used by Nousiainen et al. (2004), concentrates were offered at a flat rate irrespective of milk yield and UN was not based on total collection of urine but calculated from the difference between $\mathrm{N}$ intake and excretion of $\mathrm{N}$ in feces and milk, assuming a zero $\mathrm{N}$ balance. However, it is known from various studies in lactating dairy cows (Spanghero and Kowalski, 1997; Eriksson et al., 2004; Colmenero and Broderick, 2006), mice (Costa et al., 
1968), and humans (Young et al., 1981) that the $\mathrm{N}$ balance in general is positive due to losses of $\mathrm{N}$ from the organism not measured in urine, milk, and feces. Furthermore, differences in the MUN-UN relationships established in these studies might be related to differences in herd management, climatic conditions, type of diet, concentrate to roughage ratio of the diet, genetic makeup of the cows, or differences in techniques used to measure UN and UUN. Recently, the effect of such factors has been reviewed by Spek et al. (2013). During the last decade, more attention has been paid to the relationship between MUN and UUN instead of UN, because UUN is most strongly related to ammonia emission (Burgos et al., 2007). At present, only a few studies (Burgos et al., 2007; Powell et al., 2011) have focused on prediction of UUN by MUN. No studies have been published on the prediction of UUN from multiple animal- and dietary-related factors. For the present study, we hypothesized that the prediction accuracy of UN and UUN may be improved by selection of only those trials where UN and UUN are analyzed based on total collection of urine, instead of estimating UN and UUN based on the difference between $\mathrm{N}$ intake and excretion of $\mathrm{N}$ in milk and feces, or based on analysis of UN and UUN in urine spot samples with daily volume of urine estimated from creatinine levels in the same urine spot samples. For practical and animal welfare reasons, it might be argued to determine UN based on the difference between $\mathrm{N}$ intake and $\mathrm{N}$ excreted in feces and milk instead of using indwelling urine catheters. However, no studies have been carried out that have tested whether the relationship between MUN and UN is actually similar for UN derived from total collection of urine, or for UN calculated as the difference between $\mathrm{N}$ intake and $\mathrm{N}$ excreted in feces and milk.

The first objective of this study was to quantify the relationship between various dietary and animal factors and UN or UUN for either EU or NA data sets and to compare their respective prediction equations. The second objective of this study was to test whether the accuracy and precision of UN and UUN prediction equations are affected by the method of measuring UN and UUN, namely, estimation of UN and UUN from urine spot samples or by calculations assuming a zero $\mathrm{N}$ balance, versus UN and UUN determined by total collection of urine only.

\section{MATERIALS AND METHODS}

\section{Data Set Selection}

Studies were selected that contained at least information on (1) the partitioning of $\mathrm{N}$ excretion in urine, feces, and milk, (2) MUN, (3) DMI (kg/d) and com- position of the ration, and (4) milk production and fat and protein content in milk. Mean treatment data (n $=200)$ from 47 trials carried out in NA $(\mathrm{n}=118)$ and $\mathrm{EU}(\mathrm{n}=82)$ were used. A description of this data set (referred to as complete data set) is presented in Table 1 and contained 193 observations on UN ( $\mathrm{n}=111$ for $\mathrm{NA}$ and $\mathrm{n}=82$ for EU) and 98 observations on UUN ( $\mathrm{n}=57$ for NA and $\mathrm{n}=41$ for NA). The appendix provides a reference list of 41 studies describing these 47 trials. Some studies described multiple trials, which explains the presence of more trials than studies. In several studies, excretion of UN and UUN was determined based on spot samples taken from the urine, or based on the calculation of UN as the difference between $\mathrm{N}$ intake and excretion of $\mathrm{N}$ in milk and feces (i.e., zero $\mathrm{N}$ balance). A reduced data set (referred to as reduced data set) was developed including only observations on UN or UUN from studies where urine was collected quantitatively. This reduced data set contained 123 observations on UN ( $\mathrm{n}=55$ for NA and $\mathrm{n}=68$ for $\mathrm{EU})$ and 63 observations on UUN ( $\mathrm{n}=22$ for NA and $\mathrm{n}=$ 41 for EU). The number of observations in the reduced data set where both UN and UUN were measured was $56(\mathrm{n}=15$ for NA and $\mathrm{n}=41$ for EU). To evaluate the effect of the assumption of a zero $\mathrm{N}$ balance on the results obtained, a new data set (number of data hence identical to that of the reduced data set) was created from the reduced data set in which data on urine $\mathrm{N}$ excretion were replaced by values calculated under assumption of a zero $\mathrm{N}$ balance.

\section{Independent and Dependent Factors}

The list of independent factors that were tested for their capacity to explain observed variation in UN and UUN included animal factors and dietary factors. These independent factors are presented in Table 1 under the headings Animal factors and Dietary factors. The dependent factors in the data set were UUN and UN. Some dietary values were missing with respect to ash, starch, and NDF. These missing values were predicted based on typical composition using the Dutch feeding tables (CVB, 2007). For all diets, values were predicted for RDP, RUP, rumen-undegradable starch, digestible protein available in the small intestine (DVE), rumendegradable protein balance $(\mathbf{O E B})$, and $\mathrm{NE}_{\mathrm{L}}$ using the Dutch feeding tables (CVB, 2007).

\section{Statistical Procedure}

Multiple regression analyses were carried out with the MIXED procedure in SAS (SAS Institute Inc., Cary, NC) with trial included as random effect and all other factors as fixed effects. Fixed effects were nested 
Table 1. Characterization of data sets used for the statistical evaluation

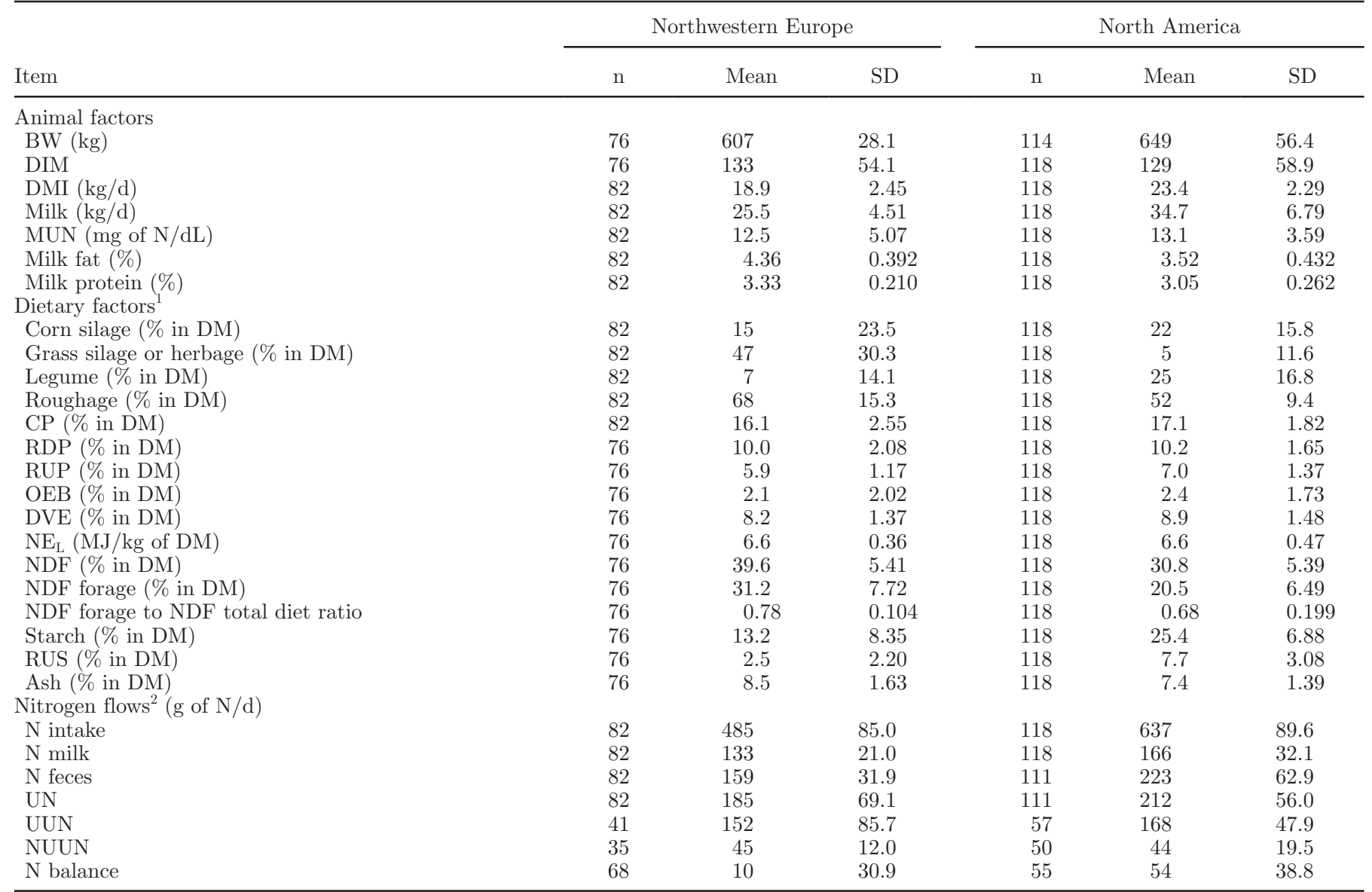

${ }^{1} \mathrm{OEB}=$ rumen-degraded protein balance (Tamminga et al., 1994); DVE = intestinal digestible protein (Tamminga et al., 1994); RUS = rumen undegradable starch.

${ }^{2} \mathrm{UN}=\mathrm{N}$ excreted in urine; $\mathrm{UUN}=$ urea $\mathrm{N}$ excreted in urine; NUUN $=$ non-urea- $\mathrm{N}$ excreted in urine. $\mathrm{N}$ balance $=$ calculated as $\mathrm{N}$-intake minus $\mathrm{N}$ excreted in urine, feces, and milk where $\mathrm{UN}$ is based on total collection of urine.

within continent (EU or NA). Univariate regression analysis of fixed factors on UN was carried out to determine those factors that explained most variation in UN from the complete data set (Table 2). Those factors that explained more than $50 \%$ of the variation in UN were combined with each of the other individual animal and dietary related factors by means of multivariate regression analysis. Based on the criteria of $R^{2}$, root mean square prediction error (RMSPE), and Akaike's information criterion (AIC) it was decided whether the other factors improved the model fit. It was assumed that observations within trial were equally correlated to each other and, therefore, the covariance structure was modeled as compound symmetry. The $\mathrm{R}^{2}$ values presented apply to the regression of predicted values of fixed effects to observed values, hence excluding the contribution of variation associated with random effect. Likewise, the RMSPE was calculated from the residuals of the fixed effects. The RMSPE was calculated accord- ing to Jonker et al. (1998). In practice, the trial effect is unknown and was not included in the calculation of RMSPE and $\mathrm{R}^{2}$, and therefore better reflects the prediction accuracy to be expected when applying the models. A COVTEST statement was included in the PROC MIXED statement to test for the effects of fixed factors on changes in between-trial variation. Data from one of the trials of Tas et al. (2006) were discarded because of very low MUN values that resulted in UN to MUN ratios more than 3 standard deviations higher than the average.

\section{RESULTS AND DISCUSSION}

\section{Data Set Evaluation}

The complete data set showed a large range in $\mathrm{CP}$ (9.4-24.1\% DM), MUN (3.8-30.2 $\mathrm{mg}$ of $\mathrm{N} / \mathrm{dL})$, DMI $(13.8-30.2 \mathrm{~kg} / \mathrm{d})$, and milk production (15.5-45.5 
Table 2. Effect of single factors on $\mathrm{N}$ excretion in urine in the complete data set as judged from the $P$-value of these single factors and the goodness of fit parameters $\mathrm{R}^{2}$ and $\mathrm{AIC}^{1}$

\begin{tabular}{lccc}
\hline Item & P-value & $\mathrm{R}^{2}$ & AIC \\
\hline Animal factors & & & \\
MUN (mg of N/dL) & $<0.001$ & 0.72 & 1,683 \\
BW (kg) & 0.050 & 0.11 & 1,932 \\
DIM & 0.480 & 0.07 & 1,979 \\
Milk (kg/d) & 0.010 & 0.01 & 2,025 \\
Milk protein (\%) & 0.449 & 0.07 & 2,019 \\
Milk fat (\%) & 0.350 & 0.05 & 2,021 \\
DMI (kg/d) & 0.008 & 0.02 & 2,021 \\
Dietary factors & & & \\
CP (\% in DM) & $<0.001$ & 0.79 & 1,700 \\
RDP (\% in DM) & $<0.001$ & 0.36 & 1,750 \\
RUP (\% in DM) & $<0.001$ & 0.38 & 1,903 \\
OEB (\% in DM) & $<0.001$ & 0.37 & 1,779 \\
DVE (\% in DM) & $<0.001$ & 0.29 & 1,925 \\
NE (MJ/kg of DM) & 0.075 & 0.12 & 1,955 \\
NDF (\% in DM) & 0.518 & 0.01 & 1,970 \\
NDF forage (\% in DM) & 0.974 & 0.06 & 1,972 \\
Starch (\% in DM) & $<0.001$ & 0.28 & 1,943 \\
RUS (\% in DM) & $<0.001$ & 0.21 & 1,950 \\
Ash (\% in DM) & 0.004 & 0.14 & 1,955 \\
Roughage (\% in DM) & 0.814 & 0.10 & 2,032 \\
\hline
\end{tabular}

${ }^{1}$ Coefficient of determination $\left(\mathrm{R}^{2}\right)$ is calculated from the total sums of squares of the model and the sums of squares explained by the fixed effect part of the model only; AIC = Akaike information criterion, a measure of the relative goodness of fit of the model; a smaller value means a better model fit.

${ }^{2} \mathrm{OEB}=$ rumen-degraded protein balance (Tamminga et al., 1994); DVE = intestinal digestible protein (Tamminga et al., 1994); RUS = rumen undegradable starch.

$\mathrm{kg} / \mathrm{d})$. The NA diets were largely based on corn silage and alfalfa and contained on average $52 \%$ roughage, whereas the EU diets were largely based on grass silage and clover silage and contained on average $68 \%$ roughage. As a consequence, the NA formulated rations contained on average $25.4 \%$ starch (DM basis) and EU rations contained $13.2 \%$ starch (DM basis). On average, NA cows produced $9.2 \mathrm{~kg} / \mathrm{d}$ more milk (34.7 vs. $25.5 \mathrm{~kg} / \mathrm{d})$, consumed $4.5 \mathrm{~kg}$ of $\mathrm{DM} / \mathrm{d}$ more feed $(23.4$ vs. $18.9 \mathrm{~kg}$ of DM/d), and were $42 \mathrm{~kg}$ heavier (649 vs. $607 \mathrm{~kg}$ ) than the EU cows. Higher standard deviations were found in the EU studies compared with NA studies for MUN (SD of 5.07 vs. 3.59), UN (SD of 69.1 vs. 56.0 ), and UUN (SD of 85.7 vs. 47.9). Daily N intake was on average $152 \mathrm{~g}$ higher in NA studies and daily excretion of $\mathrm{N}$ in milk, urine, and feces were 33,27 , and $64 \mathrm{~g}$ higher, respectively. Average MUN was $0.6 \mathrm{mg} /$ dL higher in NA compared with EU, in line with the higher UN and UUN, but lower than would be expected considering the 27 (UN) and 16 (UUN) g of N/d difference between EU and NA. Compared with EU data, fecal N excretion was $40 \%$ higher for NA cows, whereas DMI and CP content for NA were only 24 and $6 \%$ higher, respectively. The positive relation between fecal $\mathrm{N}$ excretion and DMI might explain the higher fecal $\mathrm{N}$ excretion for NA. Huhtanen et al. (2008) observed a 9.9-g increase in fecal $\mathrm{N}$ per kilogram increase of DMI. Regression of fecal $\mathrm{N}$ excretion on DMI in this study resulted in $11.3 \pm 1.07$ and $12.1 \pm 2.03 \mathrm{~g}$ of fecal N/ $\mathrm{kg}$ of DMI for EU and NA, respectively. The intercept was $17.4 \pm 48.77 \mathrm{~g}$ of fecal $\mathrm{N} / \mathrm{d}$ higher for $\mathrm{NA}$ and not statistically different from EU. Hristov et al. (2005) found a $76 \%$ higher fecal N excretion for diets supplemented with starch compared with diets supplemented with fiber and ascribed this difference in fecal $\mathrm{N}$ to differences in the amounts of microbial $\mathrm{N}$ synthesized in the large intestine and excreted in the feces. The 17.4-g higher fecal $\mathrm{N}$ excretion for NA, not being explained by DMI, might be explained by the larger amounts of rumen-undegradable starch reaching the large intestine for NA diets, resulting in an increased synthesis and fecal excretion of microbial $\mathrm{N}$.

\section{Explanatory Factors}

From all independent factors tested, the animal factor MUN and the dietary factor $\mathrm{CP}$ are the single explanatory factors in the model that explained most of the observed variation of $\mathrm{UN}\left(\mathrm{R}^{2}\right.$ of 0.72 and 0.79 , respectively; Table 3 ) and of UUN ( $\mathrm{R}^{2}$ of 0.87 and 0.81 , respectively; Table 4). Combining MUN and CP further improved the explanation of observed variation of UN and UUN (Tables 3 and 4). Although a substantial portion of variation in UN in the complete data set was explained by the single factors RUP (38\%), RDP $(36 \%)$, OEB $(37 \%)$, and DVE (29\%; Table 2$)$, these fac- 
tors did not increase the portion of explained variation when added to the model that already included MUN and CP. For UUN, a substantial part of the variation in UUN could be explained by the single factors RDP (50\%), OEB (49\%), DVE (20\%), and RUP (18\%), but, similar to UN, these factors did not increase the portion of explained variation when added to the model that already included MUN and CP. The prediction of UN was only slightly further improved when DMI was added to the model that already included MUN and CP. Milk production and BW were significant factors in explaining variation in UN when added to the model that already included MUN and CP. However, the model fit, as judged by the RMSPE and $\mathrm{R}^{2}$, did not improve and therefore these factors were excluded from the models presented in Tables 3 and 4 .

\section{Effect of Dietary and Animal Factors on UN}

More variation of UN in the complete data set was explained by $\mathrm{CP}\left(\mathrm{R}^{2}=0.79\right)$ than by $\mathrm{MUN}\left(\mathrm{R}^{2}=\right.$ $0.72)$, whereas, in the reduced data set, MUN explained slightly more variation than $\mathrm{CP}\left(\mathrm{R}^{2}=0.85\right.$ vs. 0.82$)$. However, both the complete and reduced data sets had lower AIC values when MUN was included in the model, thus favoring MUN above $\mathrm{CP}$ as a predictor of UN. Results from a meta-analysis by Nousiainen et al. (2004) suggest that, based on $\mathrm{R}^{2}$ and root mean square errors values, $\mathrm{CP}$ is a better predictor of UN than MUN ( $\mathrm{R}^{2}$ of 0.85 vs. 0.74 ). However, Nousiainen et al. (2004) did not report AIC values and, therefore, based on the combined results of the present study and the study of Nousiainen et al. (2004), it is not possible to conclude which predictor, $\mathrm{CP}$ or MUN, is preferred to predict UN. The relationship established between MUN and UN was almost identical for the complete and reduced data set, for EU as well as for NA (Figure 1; Table 3). Results of the univariate regression of UN on MUN for NA and EU were similar to values reported by Kauffman and St-Pierre (2001), Kohn et al. (2002), Nousiainen et al. (2004), and Zhai et al. (2005) at low to moderate MUN values $($ MUN $<10$ $\mathrm{mg}$ of $\mathrm{N} / \mathrm{dL}$ ). Predicted values of UN from the studies of Kauffman and St-Pierre (2001), Kohn et al. (2002), Nousiainen et al. (2004), and predicted values of NA in the present study diverged (became larger) at higher MUN values from predicted values in the study of Zhai et al. (2005) and predicted values of EU in the present study (Figure 1).

Multiple regression of MUN and CP on UN improved the explanation of UN substantially as judged by the AIC, $\mathrm{R}^{2}$, and RMSPE for both the complete (model 3; Table 3), reduced (model 7; Table 3), NA, and EU data sets. Furthermore, this model lowered the differences in regression coefficients for MUN, but increased the differences in regression coefficients for $\mathrm{CP}$ between $\mathrm{EU}$ and NA. Besides the increase in differences between regression coefficients for $\mathrm{CP}$ for $\mathrm{EU}$ and NA, the differences in intercepts between NA and EU increased as well, from 10.2 to $65.8 \mathrm{~g}$ of N/d for the complete data set and from 15.7 to $58.0 \mathrm{~g}$ of N/d for the reduced data set, respectively, indicating an interaction between $\mathrm{CP}$ and MUN. Indeed, a positive significant interaction between MUN and CP was observed for the complete data set $(P=0.006)$ and reduced data set $(P=0.006)$. Apparently, CP and MUN are not completely confounded in explaining variation in UN, as can be observed from the increased explanation of variation in UN when both factors are included in the model compared with univariate models containing either MUN or CP. The interaction between $\mathrm{CP}$ and MUN is another indication that CP and MUN are not completely confounded with respect to explaining variation in UN. Nousiainen et al. (2004) observed a positive linear relationship between MUN and CP; MUN $(\mathrm{mg}$ of $\mathrm{N} / \mathrm{dL})=1.7 \times \mathrm{CP}(\%$ in $\mathrm{DM})-14.2$ with an $\mathrm{R}^{2}$ of 0.78 . In the present study, a similar relationship was established between $\mathrm{CP}$ and MUN for EU $\left(\mathrm{R}^{2}=0.75\right)$ but a weaker one for NA $\left(\mathrm{R}^{2}\right.$ $=0.47$; Figure 2). The fact that a substantial part of the variation in MUN is not explained by CP indicates that, at a given level of CP, the level of MUN varies due to factors other than CP. Factors that might explain this unexplained variation in MUN are numerous and related to differences in nutrition and management and differences between cows. For instance, nutritional factors that affect MUN, but are unrelated to CP, include the partition of CP in RDP and RUP (Broderick et al., 1993), the dietary intake of salt and water (Burgos et al., 2001; Spek et al., 2012), or dietary energy content (Broderick and Clayton, 1997). Examples of management factors that affect MUN, but not CP, are the time and frequency of feeding and milking, which can both affect the diurnal pattern of MUN (Gustafsson and Palmquist, 1993; Friggens and Rasmussen, 2001). Differences between cows with respect to milk protein production might affect the partition of degraded and absorbed protein into milk protein and urea formed with protein catabolism, thereby affecting the relationship between MUN and CP (Huhtanen and Hristov, 2010). Furthermore, the need of the animal to retain $\mathrm{N}$ at low levels of $\mathrm{N}$ intake affects the renal regulation of urea excretion. Several studies in sheep (SchmidtNielsen et al., 1958), goats (Eriksson and Valtonen, 1982), and cattle (Thornton, 1970) show that a reduction in CP can result in a reduced renal urea clearance rate and increased renal urea reabsorption. These kidney-related factors affect the pool of urea and the distribution of urea in the cow and, as a result, affect 
CATTLE URINARY NITROGEN EXCRETION PREDICTION

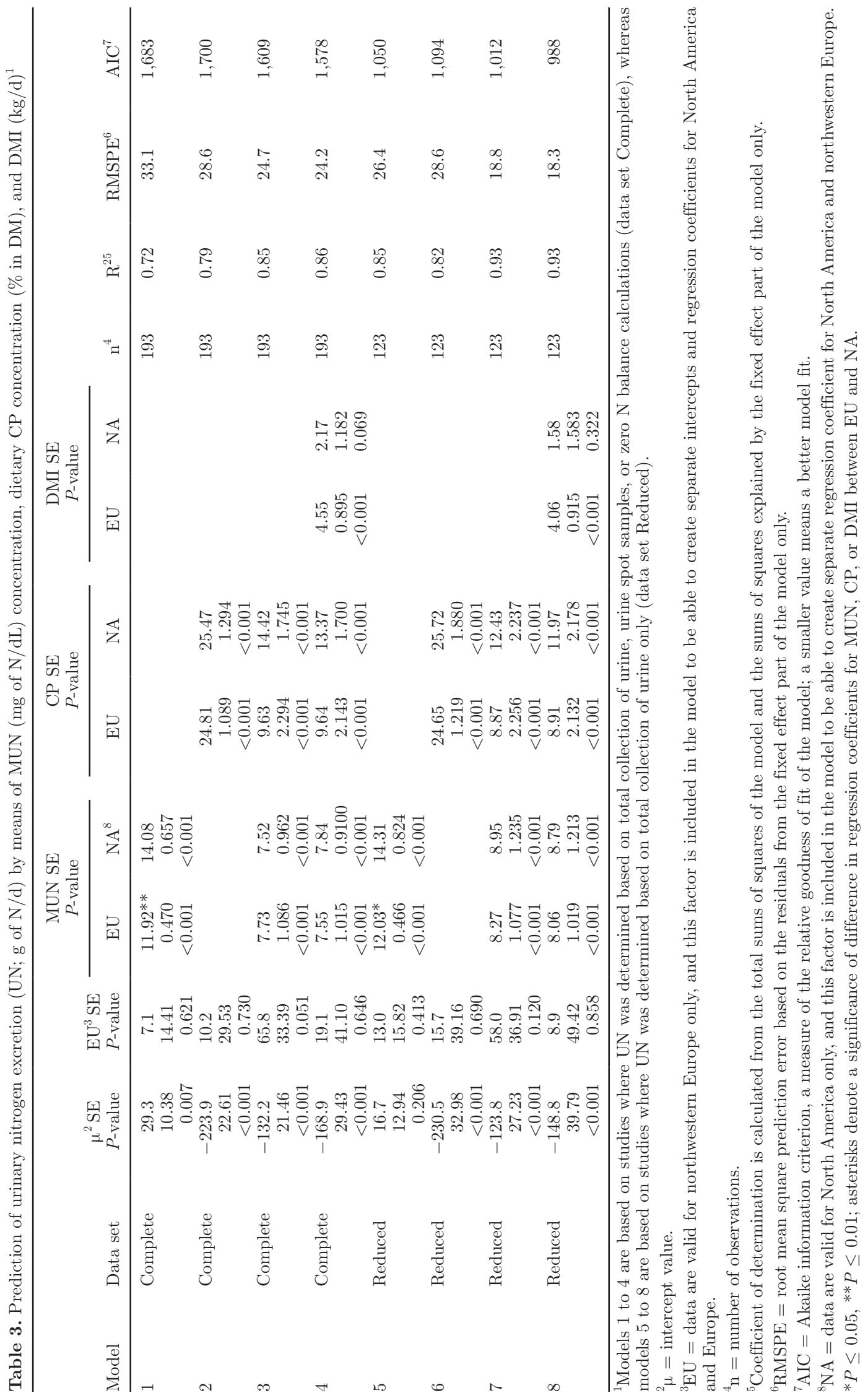


Table 4. Prediction of urinary urea nitrogen excretion (UUN; g of N/d) by means of MUN (mg of N/dL) concentration and dietary CP concentration $(\% \text { in DM })^{1}$

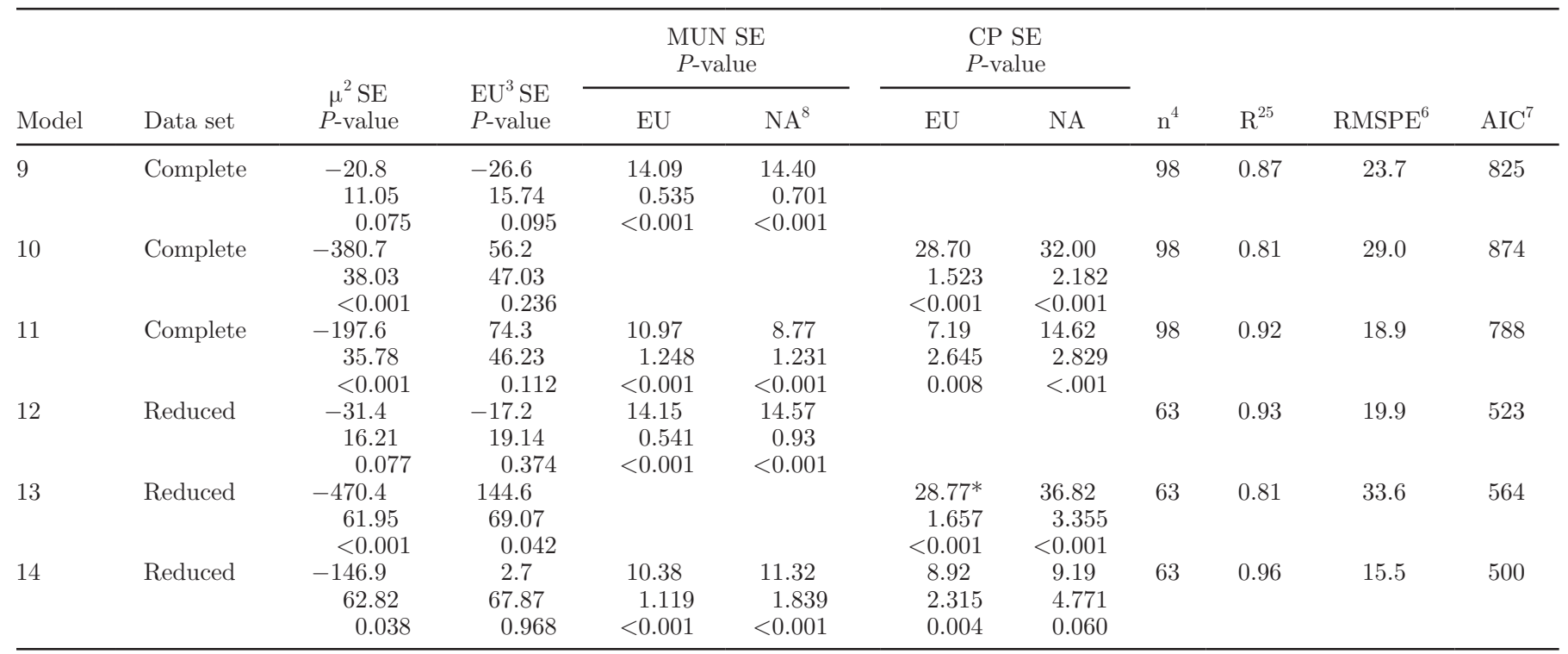

\footnotetext{
${ }^{1}$ Models 9 to 11 are based on studies where UUN was determined based on total collection of urine, urine spot samples, and zero $\mathrm{N}$ balance calculations (data set Complete), whereas models 12 to 14 are based on studies where UUN was determined based on total collection of urine only (data set Reduced)

${ }^{2} \mu=$ intercept value.

${ }^{3} \mathrm{EU}=$ data are valid for northwestern Europe only, and this factor is included in the model to be able to create separate intercepts and regression coefficients for North America and Europe.

${ }^{4} \mathrm{n}=$ number of observations.

${ }^{5}$ Coefficient of determination is calculated from the total sums of squares of the model and the sums of squares explained by the fixed effect part of the model only.

${ }^{6} \mathrm{RMSPE}=$ root mean square prediction error based on the residuals from the fixed effect part of the model only.

${ }^{7} \mathrm{AIC}=$ Akaike information criterion, a measure of the relative goodness of fit of the model; a smaller value means a better model fit.

${ }^{8} \mathrm{NA}=$ data are valid for North America only, and this factor is included in the model to be able to create separate regression coefficient for North America and northwestern Europe.

${ }^{*} P \leq 0.05$; an asterisk denotes a significance of difference in regression coefficients for MUN, CP, or DMI between EU and NA.
}

concentrations of urea nitrogen in blood plasma and MUN. All sources of variation mentioned above might underlie the moderate relationship observed between MUN and CP. The same sources of variation may be responsible for the added effect of MUN and CP in predicting UN. In the present study, indications were also noted for an increase in renal recycling of urea at low dietary $\mathrm{CP}$, as observed from differences in quantities of urinary urea $\mathrm{N}$ excreted per unit increase in MUN at low and high protein diets. For example, regression of UUN on MUN for the reduced data set resulted in lower regression coefficients for MUN for EU (8.01 \pm 2.683) for a subdata set with only CP values lower than average $\mathrm{CP}$, compared with regression coefficients for EU $(13.70 \pm 0.759)$ for a subdata set with $\mathrm{CP}$ values higher than average CP. These differences in regression coefficients of MUN between high- and low-protein subdata sets in predicting UUN are also reflected by the positive interaction between $\mathrm{CP}$ and MUN in the complete $(P=0.006)$ and reduced $(P=0.006)$ data sets in predicting UN, even though inclusion of the CP $\times$ MUN interaction did not improve model fit. These differences in regression coefficients for MUN found in the subdata set with low $\mathrm{CP}$ values and those observed in the subdata set with high $\mathrm{CP}$ values might explain differences in UN-MUN relationships found between various studies, and might also explain differences in UN-MUN relationships observed in the present data set between NA and EU data.

Addition of DMI to the model containing MUN and CP (models 4 and 8; Table 3) slightly improved the model fit of UN without a pronounced effect on regression coefficients of MUN and CP (Table 3). However, the difference in intercept values between EU and NA was reduced. The effect of DMI on UN was larger for EU than NA and is likely related to the positive and significant relation between $\mathrm{CP}$ and DMI for NA in the complete $(P=0.044)$ and reduced $(P=0.040)$ data set, whereas no such relationship was established for EU in the complete $(P=0.530)$ and reduced $(P$ 


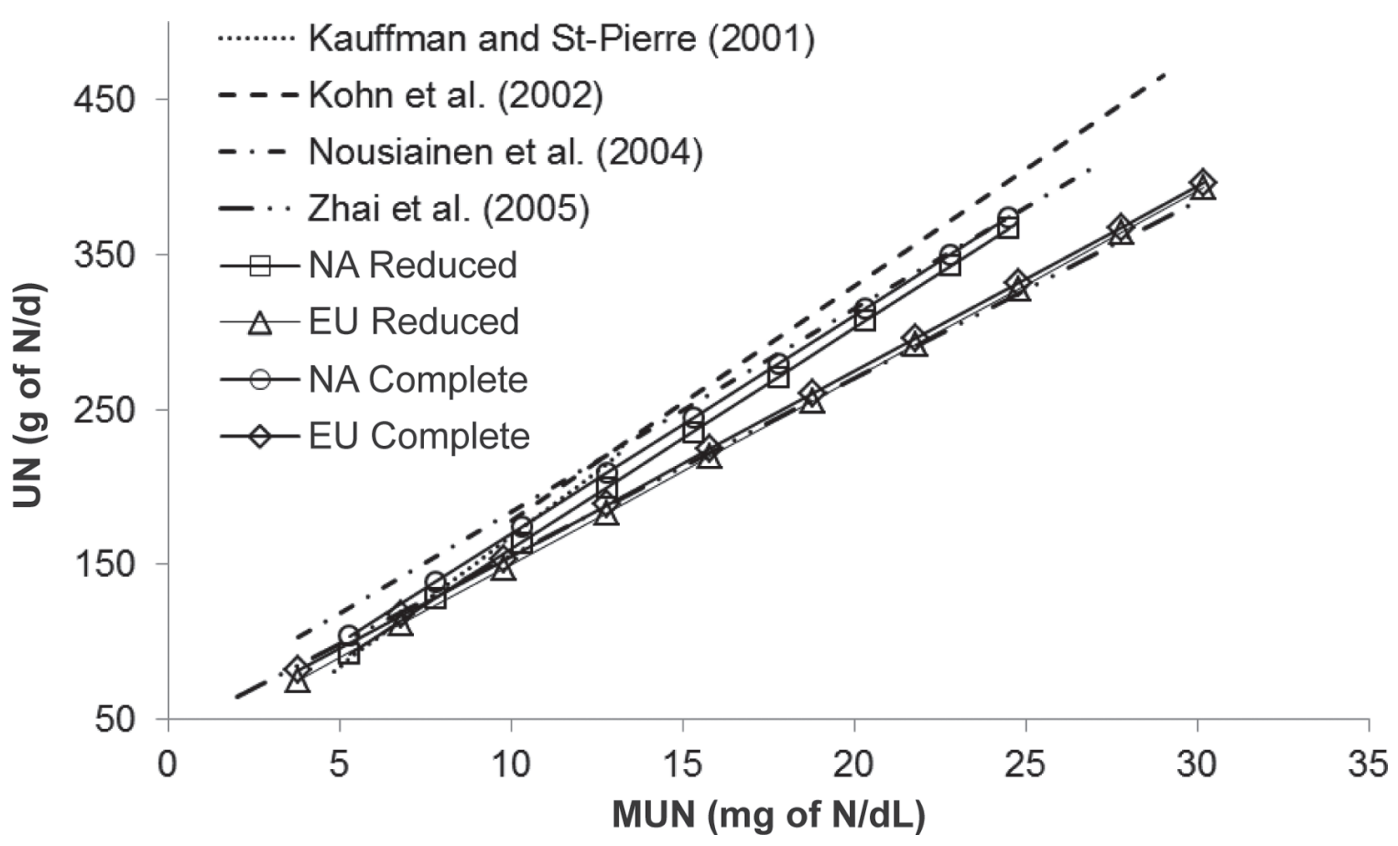

Figure 1. Relationship between MUN ( $\mathrm{mg}$ of N/dL) and urinary nitrogen excretion (UN; $\mathrm{g}$ of N/d) for northwestern Europe (EU) and North America (NA). Urinary nitrogen excretion is determined based on the complete data set (Complete; $\mathrm{n}=193$ ) or based on the reduced data set (Reduced; $\mathrm{n}=123$ ) in this study and for other studies (Kauffman and St-Pierre, 2001; Kohn et al., 2002; Nousiainen et al., 2004; Zhai et al., 2005).

$=0.590)$ data set. The authors of the present study have no explanation for these differences in CP-DMI relationships between NA and EU.

\section{Effect of Dietary and Animal Factors on UUN}

Variation in UUN was largely explained by MUN (models 9 and 12; Table 4) and CP (models 10 and 13; Table 4) with the complete as well as the reduced data set. Milk urea nitrogen explained a larger fraction $\left(\mathrm{R}^{2}=0.87-0.93\right)$ of observed variation in UUN than $\mathrm{CP}\left(\mathrm{R}^{2}=0.81\right)$, with $93 \%$ of variation in UUN explained for the in EU data and $75 \%$ in the NA data. The fact that more variation of UUN was explained in EU compared with NA data may be related to the larger variation in the $\mathrm{EU}$ data versus the NA data for UUN $(152 \pm 85.7$ vs. $168 \pm 47.9 \mathrm{~g}$ of $\mathrm{N} / \mathrm{d})$ and MUN $(12.5 \pm 5.07$ vs. $13.1 \pm 3.59 \mathrm{mg}$ of $\mathrm{N} / \mathrm{dL})$. The slope of MUN on UUN was similar for EU (14.09 and 14.15 for the complete and reduced data set, respectively) and NA (14.40 and 14.57 for the complete and reduced data set, respectively); whereas the intercept value of UUN tended to be lower for the EU than the NA data set for both the complete and reduced data set. Burgos et al. (2007) and Powell et al. (2011) observed regression coefficients for MUN of 14.4 and $16.2 \mathrm{~g}$ of UUN/d per unit of MUN, respectively. The model prediction of Burgos et al. (2007) was based on a single study, whereas the model prediction of Powell et al. (2011) was based on a simple regression of UUN on MUN data from 9 studies without correction for trial effect. The reason that a higher regression coefficient for MUN was found by Powell et al. (2011) compared with Burgos et al. (2007) and results from the present study might be the consequence of not accounting for trial effect, as shown to be necessary by St-Pierre (2001). Extrapolation of the model prediction of UUN by CP (model 13;

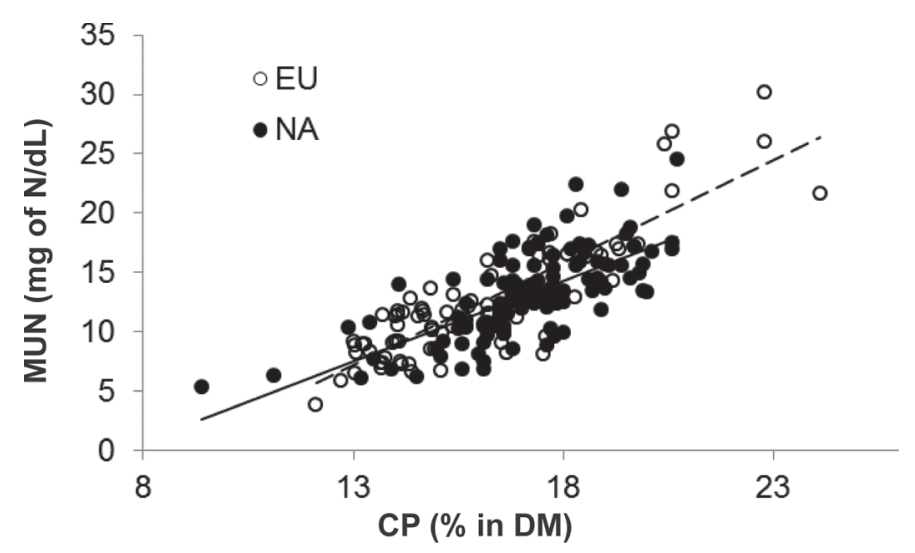

Figure 2. Relationship between dietary CP content (\% in DM) and MUN (mg of N/dL) for northwestern Europe (EU; $\mathrm{n}=82$ ) and North America (NA; $\mathrm{n}=118$ ) based on the complete data set. For NA (solid regression line), MUN $=-10.1 \pm 2.29+1.36 \pm 0.133 \times \mathrm{CP}, \mathrm{R}^{2}=$ 0.47. For EU (dashed regression line), $\mathrm{MUN}=-15.3 \pm 1.80+1.73 \pm$ $0.111 \times \mathrm{CP}, \mathrm{R}^{2}=0.75$ 


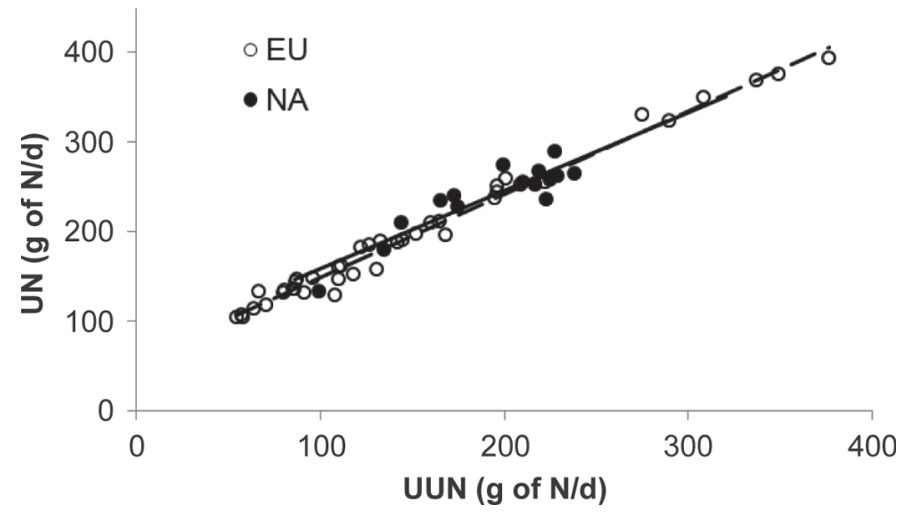

Figure 3. Relationship between urinary urea nitrogen excretion (UUN; $g$ of $\mathrm{N} / \mathrm{d}$ ) and urinary total nitrogen excretion (UN; $g$ of N/d) for northwestern Europe (EU; $\mathrm{n}=41$ ) and North America (NA; $\mathrm{n}=$ 15) based on the reduced data set. For NA (solid regression line), UN $=72.3 \pm 22.49+0.866 \pm 0.1147 \times \mathrm{UUN}, \mathrm{R}^{2}=0.81$. For EU (dashed regression line), $\mathrm{UN}=55.4 \pm 3.14+0.932 \pm 0.0181 \times \mathrm{UUN}, \mathrm{R}^{2}=$ 0.99 .

Table 4) suggests that UUN would become zero at a $\mathrm{CP}$ of 12.8 and $11.3 \%$ with the NA and the EU data, respectively, suggesting that these $\mathrm{CP}$ values indicate the highest possible $\mathrm{N}$ utilization with no loss of urea excreted in urine. Few studies have determined minimal UN or UUN excretion in dairy cows. In one study, Wohlt et al. (1978) measured a UN of 35 to $38 \mathrm{~g}$ of N/d at CP of 9.4 to $10.3 \%$, a UN of 57 to $63 \mathrm{~g}$ of $\mathrm{N} / \mathrm{d}$ at $\mathrm{CP}$ of 11.6 to $12.0 \%$, and a UN of 115 to $137 \mathrm{~g}$ of N/d at CP of 14.2 to $14.4 \%$. In another study, Ørskov and MacLeod (1982) measured minimal UN and UUN in pregnant, nonlactating Friesian cows receiving no dietary $\mathrm{N}$ at all and observed UN ranging from 34.2 to $42.0 \mathrm{~g}$ of $\mathrm{N} / \mathrm{d}$ and UUN ranging from 17.8 to $26.0 \mathrm{~g}$ of $\mathrm{N} / \mathrm{d}$. The similarity in UN values observed in the study of Ørskov and MacLeod (1982) and those observed in the study of Wohlt et al. (1978), at CP ranging from 9.4 to $12.0 \%$, indicate that the cow is able to reduce the excretion of UN to 34 to $42 \mathrm{~g}$ of $\mathrm{N} / \mathrm{d}$. A third study, a review on urea excretion and recycling to the gastrointestinal tract (Reynolds and Kristensen, 2008), demonstrated that ruminants are able to reduce urea excretion at low $\mathrm{CP}$, and observed that at a $\mathrm{CP}$ of $7.5 \%$ the amount of urea excreted as a proportion of urea produced became close to zero. The database used in the present study indicates an average nonurea urinary nitrogen excretion $(\mathrm{g}$ of $\mathrm{N} / \mathrm{d}$ ) of $45 \pm 12.0$ and $44 \pm 19.5 \mathrm{~g}$ of $\mathrm{N} / \mathrm{d}$ for the EU and NA data set, respectively (Table 1). It was expected that regression coefficients for MUN and $\mathrm{CP}$ versus UUN would be similar to those obtained in the UN equation, as UUN and UN are strongly related (Burgos et al., 2005; Figure 3). This was indeed the case for the NA data set, where MUN regression coefficients of UN models for both the complete (14.08) and reduced (14.31) data sets (Table 3) were similar to the MUN regression coefficients (14.40 and 14.57, respectively) of the UUN models (Table 4). However, for the EU data set, MUN regression coefficients of the UN models for the complete (11.92) and reduced (12.03) data sets (Table 3) were lower than the MUN regression coefficients (14.09 and 14.15, respectively) of the UUN models (Table 4). Removal of extreme MUN observations ( $>25 \mathrm{mg}$ of $\mathrm{N} / \mathrm{d}$ ) from the EU data set reduced the MUN regression coefficients for UUN from 14.15 to 12.71 in the reduced data set and from 14.09 to 12.62 in the complete data set, and became similar to those obtained for UN. The observations with MUN values higher than $25 \mathrm{mg}$ of $\mathrm{N} / \mathrm{dL}$ in the EU data set were, therefore, probably responsible for this effect. Regression coefficients of CP were higher in the UUN models for the complete and reduced data set (models 10 and 13; Table 4) compared with those for the UN models, in particular for the NA data set.

Similar to the prediction of UN, the combination of MUN and CP in both the complete and reduced data set (models 11 and 14, respectively; Table 4) resulted in a better prediction of UUN than with MUN or CP as the single explanatory factor, lowering the AIC and RMSPE substantially. The same physiological explanation as given for the added effect of MUN and CP in explaining UN holds for UUN. Addition of other dietary or animal factors did not improve the explanation of UUN.

\section{Between-Trial Variation}

Between-trial variation for UN in a model containing only the class variable continent (NA or EU) was substantially reduced when MUN (reduction of 63 and $80 \%$ for the complete and reduced data set, respectively), CP (reduction of 77 and $80 \%$ for the complete and reduced data set, respectively), or the combination of MUN and CP (reduction of 82 and $93 \%$ for the complete and reduced data set, respectively) was included in the model. Between-trial variation for UUN in a model containing only the class variable continent (NA or EU) was substantially reduced when MUN (reduction of 78 and $91 \%$ for the complete and reduced data set, respectively), CP (reduction of 73 and $70 \%$ for the complete and reduced data set, respectively), or the combination of MUN and CP (reduction of 87 and $97 \%$ for the complete and reduced data set, respectively) was included in the model. Trial effect was significant in all cases except for the multivariate model containing MUN and CP that predicted UUN for the reduced data set $(P=0.066)$. The reduction in between-trial variation upon including MUN, CP, or the combination of MUN and CP in the model is not surprising 


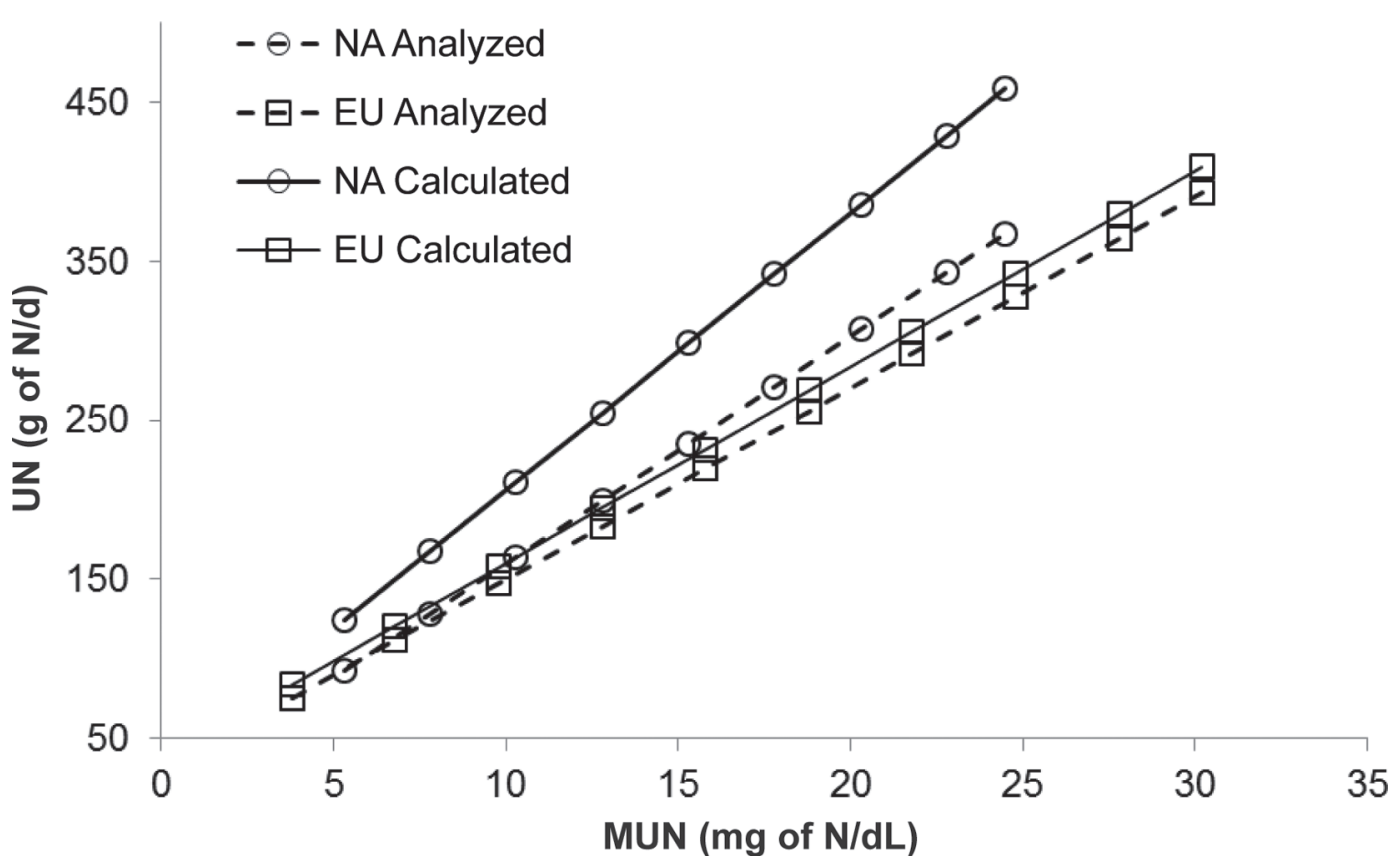

Figure 4. Relationship between MUN ( $\mathrm{mg}$ of N/dL) and urinary nitrogen excretion (UN; $\mathrm{g}$ of N/d) based on data from the reduced data set for northwestern Europe $(\mathrm{EU} ; \mathrm{n}=68)$ and North America $(\mathrm{NA} ; \mathrm{n}=55)$. Urinary nitrogen excretion is determined based on total collection of urine (Analyzed) or based on calculation of UN as the difference between $\mathrm{N}$ intake and $\mathrm{N}$ excreted in feces and milk (Calculated). The UN Analyzed prediction model is presented in model 5 (Table 3). The UN Calculated prediction model is $\mu=31.4 \pm 21.22 ; \mathrm{EU}=5.6 \pm 25.94 ; \mathrm{EU}$ regression coefficient for MUN $=12.33 \pm 0.764$; NA regression coefficient for MUN $=17.46 \pm 1.352$; Akaike's information criterion $=1,168$; root mean square prediction error $=43.8 ; \mathrm{R}^{2}=0.79$.

and can be explained by the variation in UN and UUN explained by MUN and CP. The significance of trial effect in almost all cases indicates additional explainable variation is present.

\section{Precision and Accuracy}

A more precise explanation of UN and UUN was obtained with the reduced data set, containing only observations on UN and UUN based on the total collection of urine, compared with the complete data set, as judged by the $\mathrm{R}^{2}$ and RMSPE. The RMSPE obtained for UN using both MUN and $\mathrm{CP}$ as independent variables in the model was reduced by $24 \%$ (from 24.7 to 18.8; models 3 and 7 in Table 3). The RMSPE obtained for UN using MUN, CP, and DMI as independent variables in the model was reduced by $24 \%$ as well (from 24.2 to 18.3 ; models 4 and 8 in Table 3). The RMSPE for the UUN data set using both MUN and CP as independent variables in the model was reduced by $18 \%$ (from 18.9 to 15.5 ; models 11 and 14 in Table 4). These substantial reductions in RMSPE for the reduced data set (vs. complete data set) demonstrates the importance of analyzing UN and UUN based on the total collection of urine instead of determining UN and UUN from urine spot samples or by assuming zero $\mathrm{N}$ balance. Although for the reason of precision it is best to estimate UN based on total collection of urine (UN-analyzed), from a practical and animal welfare point of view it might be preferred to derive UN by assuming a zero $\mathrm{N}$ balance and calculate $\mathrm{UN}$ as the difference between $\mathrm{N}$ intake and $\mathrm{N}$ excreted in feces and milk (UN calculated). Although precision of UN calculated will be lower, little is known about the effect of calculating UN based on zero $\mathrm{N}$ balance on accuracy. The MUN-UN calculated relationship and the MUN-UN analyzed relationship for the same reduced data set were compared and it appeared that these relationships were similar for EU but substantially different for NA (Figure 4). For the EU data set, the combined intercept and the slope were 29.7 and $12.03 \pm$ 0.466 for the analyzed data, and 37.0 and $12.33 \pm 0.764$ for the calculated data. The relationship between UN and MUN for the NA data set had a higher regression coefficient for MUN when UN was calculated (17.46 \pm 1.352; Figure 4) as compared with UN measured (14.31 \pm 0.824 ; model 5 in Table 3$)$. These results indicate that the accuracy of MUN in predicting UN is sensitive to the method of UN determination. The higher UN calculated, compared with UN analyzed, can only be explained by a high positive $\mathrm{N}$ balance for NA. The reduced data set average $\mathrm{N}$ balance was $54 \pm 38.8 \mathrm{~g}$ 
of $\mathrm{N} / \mathrm{d}$ for NA and substantially larger than the average $\mathrm{N}$ balance for $\mathrm{EU}$ of $10.1 \pm 30.9 \mathrm{~g}$ of $\mathrm{N} / \mathrm{d}$ (Table 1). It is unclear why the $\mathrm{N}$ balance is higher for the NA than for the EU data set. Spanghero and Kowalski (1997) observed from a meta-analysis on N balance trials (35 studies, 27 from NA and 8 from EU) an average positive $\mathrm{N}$ balance of $39 \mathrm{~g}$ of $\mathrm{N} / \mathrm{d}$, which seems in line with the findings in the present study for the NA data set. Spanghero and Kowalski (1997) also observed a positive relationship between digestible $\mathrm{N}$ intake and $\mathrm{N}$ balance. This positive relationship might also explain the difference in $\mathrm{N}$ balance between $\mathrm{EU}$ and NA, as $\mathrm{N}$ intake (and probably also digestible $\mathrm{N}$ intake) was on average $31 \%$ higher for NA (637 g of $\mathrm{N} / \mathrm{d}$ ) compared with $\mathrm{EU}(485 \mathrm{~g}$ of $\mathrm{N} / \mathrm{d})$.

\section{CONCLUSIONS}

Variation in UN and UUN for EU and NA was best explained by the combination of MUN and CP. Addition of DMI to the model further improved the explanation of UN for EU, but not for NA. Other animal and dietary factors tested in this study did not improve or only marginally improved the model fit of UN and UUN. The relationship between UN and MUN differed between NA and EU, with higher estimated regression coefficients for MUN for the NA data set. Prediction precision of UN and UUN was improved substantially by including only those studies in which UN and UUN were based on total collection of urine instead of being derived from spot samples or by assumption of zero $\mathrm{N}$ balance. In regard to precision and accuracy, relations between MUN and UN should be based on UN derived from total collection of urine, whereas establishing relationships between MUN and UN, where UN is calculated as $\mathrm{N}$ intake minus $\mathrm{N}$ excreted in milk and feces, is likely to yield inaccurate and imprecise relationships. We concluded that on-farm prediction of UN or UUN can be substantially improved by using MUN and CP, compared with either MUN or CP alone, and might help in monitoring and in taking policy measures to reduce environmental $\mathrm{N}$ losses.

\section{ACKNOWLEDGMENTS}

This study was funded by the Dutch Dairy Board (Zoetermeer, the Netherlands), the Dutch Product Board Animal Feed (The Hague, the Netherlands) and the Dutch Ministry of Economic affairs, Agriculture and Innovation (The Hague, the Netherlands).

\section{REFERENCES}

Broderick, G. A., and M. K. Clayton. 1997. A statistical evaluation of animal and nutritional factors influencing concentrations of milk urea nitrogen. J. Dairy Sci. 80:2964-2971.
Broderick, G. A., W. M. Craig, and D. B. Ricker. 1993. Urea versus true protein as supplement for lactating dairy cows fed grain plus mixtures of alfalfa and corn silages. J. Dairy Sci. 76:2266-2274.

Burgos, M. S., M. Senn, F. Sutter, M. Kreuzer, and W. Langhans. 2001. Effect of water restriction on feeding and metabolism in dairy cows. Am. J. Physiol. Regul. Integr. Comp. Physiol. 280:418-427.

Burgos, S. A., J. G. Fadel, and E. J. DePeters. 2007. Prediction of ammonia emission from dairy cattle manure based on milk urea nitrogen: Relation of milk urea nitrogen to urine urea nitrogen excretion. J. Dairy Sci. 90:5499-5508.

Burgos, S. A., P. H. Robinson, J. G. Fadel, and E. J. DePeters. 2005 Ammonia volatilization potential: Prediction of urinary urea nitrogen output in lactating dairy cows. Agric. Ecosyst. Environ. 111:261-269.

Colmenero, J. J. O., and G. A. Broderick. 2006. Effect of dietary crude protein concentration on milk production and nitrogen utilization in lactating dairy cows. J. Dairy Sci. 89:1704-1712.

Costa, G., L. Ullrich, F. Kantor, and J. F. Holland. 1968. Production of elemental nitrogen by certain mammals including man. Nature 218:546-551.

CVB. 2007. Table of feedstuffs. Information about composition, digestibility and feeding value. Centraal Veevoederbureau, Lelystad, the Netherlands.

de Vries, W., H. Kros, and O. Oenema. 2001. Modeled impacts of farming practices and structural agricultural changes on nitrogen fluxes in the Netherlands. ScientificWorldJournal 1:664-672.

Eriksson, L., and M. Valtonen. 1982. Renal urea handling in goats fed high and low protein diets. J. Dairy Sci. 65:385-389.

Eriksson, T., M. Murphy, P. Ciszuk, and E. Burstedt. 2004. Nitrogen balance, microbial protein production, and milk production in dairy cows fed fodder beets and potatoes, or barley. J. Dairy Sci. 87:1057-1070.

Friggens, N. C., and M. D. Rasmussen. 2001. Milk quality assessment in automatic milking systems: Accounting for the effects of variable intervals between milkings on milk composition. Livest. Prod. Sci. $73: 45-54$.

Gustafsson, A. H., and D. L. Palmquist. 1993. Diurnal variation of rumen ammonia, serum urea, and milk urea in dairy cows at high and low yields. J. Dairy Sci. 76:475-484.

Hristov, A. N., J. K. Ropp, K. L. Grandeen, S. Abedi, R. P. Etter, A. Melgar, and A. E. Foley. 2005. Effect of carbohydrate source on ammonia utilization in lactating dairy cows. J. Anim. Sci. $83: 408-421$

Huhtanen, P. and A. N. Hristov. 2010. Effects of energy and protein supply on milk protein yield responses in dairy cows. Pages 287298 in EAAP Scientific Series. Vol. 127. Wageningen Academic Publishers, Wageningen, the Netherlands.

Huhtanen, P., J. I. Nousiainen, M. Rinne, K. Kytölä, and H. Khalili. 2008. Utilization and partition of dietary nitrogen in dairy cows fed grass silage-based diets. J. Dairy Sci. 91:3589-3599.

Jonker, J. S., R. A. Kohn, and R. A. Erdman. 1998. Using milk urea nitrogen to predict nitrogen excretion and utilization efficiency in lactating dairy cows. J. Dairy Sci. 81:2681-2692.

Kauffman, A. J., and N. R. St-Pierre. 2001. The relationship of milk urea nitrogen to urine nitrogen excretion in Holstein and Jersey cows. J. Dairy Sci. 84:2284-2294.

Kohn, R. A., K. F. Kalscheur, and E. Russek-Cohen. 2002. Evaluation of models to estimate urinary nitrogen and expected milk urea nitrogen. J. Dairy Sci. 85:227-233.

Nousiainen, J., K. J. Shingfield, and P. Huhtanen. 2004. Evaluation of milk urea nitrogen as a diagnostic of protein feeding. J. Dairy Sci. 87:386-398.

Ørskov, E. R., and N. A. MacLeod. 1982. The determination of the minimal nitrogen excretion in steers and dairy cows and its physiological and practical implications. Br. J. Nutr. 47:625-626.

Powell, J. M., M. A. Wattiaux, and G. A. Broderick. 2011. Short communication: Evaluation of milk urea nitrogen as a management tool to reduce ammonia emissions from dairy farms. J. Dairy Sci. 94:4690-4694. 
Reynolds, C. K., and N. B. Kristensen. 2008. Nitrogen recycling through the gut and the nitrogen economy of ruminants: An asynchronous symbiosis. J. Anim. Sci. 86:E293-305.

Schmidt-Nielsen, B., H. Osaki, H. V. J. Murdaugh, and R. O'Dell. 1958. Renal regulation of urea excretion in sheep. Am. J. Physiol. 194:221-228

Spanghero, M., and Z. M. Kowalski. 1997. Critical analysis of N balance experiments with lactating cows. Livest. Prod. Sci. 52:113122.

Spek, J. W., A. Bannink, G. Gort, W. H. Hendriks, and J. Dijkstra. 2012. Effect of sodium chloride intake on urine volume, urinary urea excretion, and milk urea concentration in dairy cattle. J. Dairy Sci. 95:7288-7298.

Spek, J. W., J. Dijkstra, G. Van Duinkerken, and A. Bannink. 2013. A review of factors influencing milk urea concentration and its relationship with urinary urea excretion in lactating dairy cattle. J. Agric. Sci. 151:407-423. http://dx.doi.org/10.1017/ S0021859612000561.

St-Pierre, N. R. 2001. Invited review: Integrating quantitative findings from multiple studies using mixed model methodology. J. Dairy Sci. 84:741-755

Tamminga, S., W. M. Van Straalen, A. P. J. Subnel, R. G. M. Meijer, A. Steg, C. J. G. Wever, and M. C. Blok. 1994. The Dutch protein evaluation system: The DVE/OEB-system. Livest. Prod. Sci. 40:139-155.

Tas, B. M., H. Z. Taweel, H. J. Smit, A. Elgersma, J. Dijkstra, and S. Tamminga. 2006. Utilisation of $\mathrm{N}$ in perennial ryegrass cultivars by stall-fed lactating dairy cows. Livest. Sci. 100:159-168.

Thornton, R. F. 1970. Factors affecting the urinary excretion of urea nitrogen in cattle. II. The plasma urea nitrogen concentration. Aust. J. Agric. Res. 21:145-152.

Van Es, A. J. H. 1975. Feed evaluation for dairy cows. Livest. Prod. Sci. 2:95-107.

Wohlt, J. E., J. H. Clark, and F. S. Blaisdell. 1978. Nutritional value of urea versus preformed protein for ruminants. II. Nitrogen utilization by dairy cows fed corn based diets containing supplemental nitrogen from urea and/or soybean meal. J. Dairy Sci. 61:916-931.

Young, V. R., N. S. Scrimshaw, and D. M. Bier. 1981. Whole body protein and amino acid metabolism: Relation to protein quality evaluation in human nutrition. J. Agric. Food Chem. 29:440-447.

Zhai, S., J. Liu, Y. Wu, and J. Ye. 2007. Predicting urinary nitrogen excretion by milk urea nitrogen in lactating Chinese Holstein cows. Anim. Sci. J. 78:395-399.

Zhai, S. W., J. X. Liu, and Y. Ma. 2005. Relation between milk urea content and nitrogen excretion from lactating cows. Acta Agric. Scand. Anim. Sci. 55:113-115.

\section{APPENDIX}

Agle, M., A. N. Hristov, S. Zaman, C. Schneider, P. Ndegwa, and V. K. Vaddella. 2010. The effects of ruminally degraded protein on rumen fermentation and ammonia losses from manure in dairy cows. J. Dairy Sci. 93:1625-1637.

Ahvenjärvi, S., A. Vanhatalo, and P. Huhtanen. 2002. Supplementing barley or rapeseed meal to dairy cows fed grass-red clover silage: I. Rumen degradability and microbial flow. J. Anim. Sci. 80:2176-2187.

Beckman, J. L., and W. P. Weiss. 2005. Nutrient digestibility of diets with different fiber to starch ratios when fed to lactating dairy cows. J. Dairy Sci. 88:1015-1023.

Borucki Castro, S. I., L. E. Phillip, H. Lapierre, P. W. Jardon, and R. Berthiaume. 2008. The relative merit of ruminal undegradable protein from soybean meal or soluble fiber from beet pulp to improve nitrogen utilization in dairy cows. J. Dairy Sci. 91:3947-3957.

Brito, A. F., and G. A. Broderick. 2006. Effect of varying dietary ratios of alfalfa silage to corn silage on production and nitrogen utilization in lactating dairy cows. J. Dairy Sci. 89:3924-3938.

Brito, A. F., and G. A. Broderick. 2007. Effects of different protein supplements on milk production and nutrient utilization in lactating dairy cows. J. Dairy Sci. 90:1816-1827.
Broderick, G. A. 2003. Effects of varying dietary protein and energy levels on the production of lactating dairy cows. J. Dairy Sci. 86:1370-1381.

Broderick, G. A., and W. J. Radloff. 2004. Effect of molasses supplementation on the production of lactating dairy cows fed diets based on alfalfa and corn silage. J. Dairy Sci. 87:2997-3009.

Broderick, G. A., and S. M. Reynal. 2009. Effect of source of rumendegraded protein on production and ruminal metabolism in lactating dairy cows. J. Dairy Sci. 92:2822-2834.

Burgos, S. A., N. M. Embertson, Y. Zhao, F. M. Mitloehner, E. J. DePeters, and J. G. Fadel. 2010. Prediction of ammonia emission from dairy cattle manure based on milk urea nitrogen: Relation of milk urea nitrogen to ammonia emissions. J. Dairy Sci. 93:2377-2386.

Cherney, D. J. R., J. H. Cherney, and L. E. Chase. 2003. Influence of dietary nonfiber carbohydrate concentration and supplementation of sucrose on lactation performance of cows fed fescue silage. J. Dairy Sci. 86:3983-3991.

Colmenero, J. J. O., and G. A. Broderick. 2006a. Effect of amount and ruminal degradability of soybean meal protein on performance of lactating dairy cows. J. Dairy Sci. 89:1635-1643.

Colmenero, J. J. O., and G. A. Broderick. 2006b. Effect of dietary crude protein concentration on milk production and nitrogen utilization in lactating dairy cows. J. Dairy Sci. 89:1704-1712.

Davidson, S., B. A. Hopkins, D. E. Diaz, S. M. Bolt, C. Brownie, V. Fellner, and L. W. Whitlow. 2003. Effects of amounts and degradability of dietary protein on lactation, nitrogen utilization, and excretion in early lactation Holstein cows. J. Dairy Sci. 86:16811689.

De Campeneere, S., J. L. de Boever, J. M. Vanacker, W. Messens, and D. L. de Brabander. 2009. Feeding measures to reduce nitrogen excretion in dairy cattle. Arch. Anim. Nutr. 63:87-103.

De Campeneere, S., D. L. De Brabander, and J. M. Vanacker. 2006. Milk urea concentration as affected by the roughage type offered to dairy cattle. Livest. Sci. 103:30-39.

De Jong, L., A. M. Van Vuuren, and J. Kogut. 1996. Kwantitatieve effecten van natrium, kalium en stikstof op de waterconsumptie en urineproduktie van de melkkoe. Intern Rapport ID-DLO no. 456, Lelystad, the Netherlands.

Eriksson, T., M. Murphy, P. Ciszuk, and E. Burstedt. 2004. Nitrogen balance, microbial protein production, and milk production in dairy cows fed fodder beets and potatoes, or barley. J. Dairy Sci. 87:1057-1070.

Flis, S. A., and M. A. Wattiaux. 2005. Effects of parity and supply of rumen-degraded and undegraded protein on production and nitrogen balance in Holsteins. J. Dairy Sci. 88:2096-2106.

Foley, A. E., A. N. Hristov, A. Melgar, J. K. Ropp, R. P. Etter, S. Zaman, C. W. Hunt, K. Huber, and W. J. Price. 2006. Effect of barley and its amylopectin content on ruminal fermentation and nitrogen utilization in lactating dairy cows. J. Dairy Sci. 89:4321-4335.

Gonda, H. L., and J. E. Lindberg. 1994. Evaluation of dietary nitrogen utilization in dairy cows based on urea concentrations in blood, urine and milk, and on urinary concentration of purine derivatives. Acta Agric. Scand. Anim. Sci. 44:236-245.

Gozho, G. N., and T. Mutsvangwa. 2008. Influence of carbohydrate source on ruminal fermentation characteristics, performance, and microbial protein synthesis in dairy cows. J. Dairy Sci. 91:27262735 .

Groff, E. B., and Z. Wu. 2005. Milk production and nitrogen excretion of dairy cows fed different amounts of protein and varying proportions of alfalfa and corn silage. J. Dairy Sci. 88:3619-3632.

Haig, P. A., T. Mutsvangwa, R. Spratt, and B. W. McBride. 2002. Effects of dietary protein solubility on nitrogen losses from lactating dairy cows and comparison with predictions from the Cornell Net Carbohydrate and Protein System. J. Dairy Sci. 85:1208-1217.

Hristov, A. N., and J. K. Ropp. 2003. Effect of dietary carbohydrate composition and availability on utilization of ruminal ammonia nitrogen for milk protein synthesis in dairy cows. J. Dairy Sci. $86: 2416-2427$. 
Hristov, A. N., J. K. Ropp, K. L. Grandeen, S. Abedi, R. P. Etter, A. Melgar, and A. E. Foley. 2005. Effect of carbohydrate source on ammonia utilization in lactating dairy cows. J. Anim. Sci. $83: 408-421$.

Kauffman, A. J., and N. R. St-Pierre. 2001. The relationship of milk urea nitrogen to urine nitrogen excretion in Holstein and Jersey cows. J. Dairy Sci. 84:2284-2294.

Korhonen, M., A. Vanhatalo, and P. Huhtanen. 2002. Effect of protein source on amino acid supply, milk production, and metabolism of plasma nutrients in dairy cows fed grass silage. J. Dairy Sci. 85:3336-3351.

Leiva, E., M. B. Hall, and H. H. Van Horn. 2000. Performance of dairy cattle fed citrus pulp or corn products as sources of neutral detergent-soluble carbohydrates. J. Dairy Sci. 83:2866-2875.

Leonardi, C., M. Stevenson, and L. E. Armentano. 2003. Effect of two levels of crude protein and methionine supplementation on performance of dairy cows. J. Dairy Sci. 86:4033-4042.

Monteils, V., S. Jurjanz, G. Blanchart, and F. Laurent. 2002. Nitrogen utilisation by dairy cows fed diets differing in crude protein level with a deficit in ruminal fermentable nitrogen. Reprod. Nutr. Dev. 42:545-557.

Reynal, S. M., and G. A. Broderick. 2005. Effect of dietary level of rumen-degraded protein on production and nitrogen metabolism in lactating dairy cows. J. Dairy Sci. 88:4045-4064.

Ruiz, R., L. O. Tedeschi, J. C. Marini, D. G. Fox, A. N. Pell, G. Jarvis, and J. B. Russell. 2002. The effect of a ruminal nitrogen (N) deficiency in dairy cows: Evaluation of the Cornell Net Carbohydrate and Protein System ruminal N deficiency adjustment. J. Dairy Sci. 85:2986-2999.
Sannes, R. A., M. A. Messman, and D. B. Vagnoni. 2002. Form of rumen-degradable carbohydrate and nitrogen on microbial protein synthesis and protein efficiency of dairy cows. J. Dairy Sci. 85:900-908

Shingfield, K. J., S. Jaakkola, and P. Huhtanen. 2001. Effects of level of nitrogen fertilizer application and various nitrogenous supplements on milk production and nitrogen utilization of dairy cows given grass silage-based diets. Anim. Sci. 73:541-554.

Tas, B. M., H. Z. Taweel, H. J. Smit, A. Elgersma, J. Dijkstra, and S. Tamminga. 2006. Utilisation of $\mathrm{N}$ in perennial ryegrass cultivars by stall-fed lactating dairy cows. Livest. Sci. 100:159-168.

Valk, H., A. M. Van Vuuren, and A. C. Beynen. 2002. Effect of grassland fertilizer on urinary and fecal concentrations of nitrogen and phosphorus in grass-fed dairy cows. Page 204 in $\mathrm{PhD}$ Thesis, Utrecht University, Utrecht, the Netherlands.

Van Vuuren, A. M., A. Klop, and H. De Visser. 1998. Effect van bierbostel met of zonder citruspulp op de vertering en benutting van eiwit door melkkoeien. ID-DLO-rapport 98.004, Lelystad, the Netherlands.

Vanhatalo, A., K. Kuoppala, S. Ahvenjarvi, and M. Rinne. 2009. Effects of feeding grass or red clover silage cut at two maturity stages in dairy cows. 1. Nitrogen metabolism and supply of amino acids. J. Dairy Sci. 92:5620-5633.

Wattiaux, M. A., and K. L. Karg. 2004a. Protein level for alfalfa and corn silage-based diets: I. Lactational response and milk urea nitrogen. J. Dairy Sci. 87:3480-3491.

Wattiaux, M. A., and K. L. Karg. 2004b. Protein level for alfalfa and corn silage-based diets: II. Nitrogen balance and manure characteristics. J. Dairy Sci. 87:3492-3502. 